African Crop Science Journal by African Crop Science Society is licensed under a Creative Commons Attribution 3.0 Uganda License. Based on a work at www.ajol.info/ and www.bioline.org.br/cs DOI: http://dx.doi.org/10.4314/acsj.v23i4.5

\title{
INHERITANCE OF RESISTANCE TO SESAME GALL MIDGE IN UGANDA
}

\author{
W. UBOR, P. GIBSON, W. ANYANGA ${ }^{2}$ and P. RUBAIHAYO \\ 'Department of Agricultural Production, Makerere University, P. O. Box 7062, Kampala, Uganda \\ ${ }^{2}$ National Semi Arid Resources Research Institute (NaSARRI), P. O. Box Private Bag Soroti, Uganda
}

Correspondent author: uborwilliam11@gmail.com, andrea.ubor@yahoo.com

(Received 20 July, 2015; accepted 13 November, 2015)

\begin{abstract}
Sesame gall midge, caused by Asphondylia sesami Felt, is an important constraint to sesame (Sesamum indicum L.) production in Uganda. Few genotypes have been reported on sesame gall midge, especially hairy genotypes. However, for genetic improvement, there is need to understand the mode of resistance to sesame gall midge in these genotypes. Thirty sesame genotypes were screened for gall midge resistance, under field conditions at Ngetta Zonal Agricultural Research development Institute (ZARDI) in northern Uganda. The spreader row technique was used in order to increase insect pressure on the tested genotypes. The half diallel method 2, model 1 was used to cross $5 \times 5$ parents. The result showed that non-additive gene action was important in the inheritance of resistance to sesame gall midge. Cross analysis showed that the GCA $x$ site and SCA $x$ site interactions were significant $(\mathrm{P}<0.05)$, indicating that the additive and non-additive gene actions simultaneously controlled the inheritance for the resistance. The estimate of heritability in narrow sense genetic coefficient of determination (analogue heritable proportion) showed that the resistance was not highly heritable. Estimates of GCA and SCA effects suggest that the parent, Local158, was the best combiner for resistance to gall midge; while the parent AjimoA1-5 was the poorest combiner for the trait. Crosses Local158 x 7029-1-2 and Sesim1 x AjimoA1-5 were the best for the resistance to sesame gall midge. The estimates of genetic effects for resistance to sesame gall midge, showed predominance of additive and additive $\mathrm{x}$ additive type of epistasis in the inheritance of the resistance, though dominance also had a role in the cross Sesim1 x 7020-1-2.
\end{abstract}

Key Words: Asphondylia sesami, combining ability, GCA, Sesamum indicum

\section{RÉSUMÉ}

La cécidomyie du sesame, causée par Asphondylia sesami Felt, est une contrainte majeure à la production du sésame (Sesamum indicum L.) en Ouganda. Très peu de génotypes résistants à la cécidomyie de sésame ont été enregistrés, en particulier les génotypes à pubescence. Cependant, pour une amélioration génétique, il est nécessaire de comprendre le mode de résistance en jeu. Trente génotypes de sésame ont été évalués en plein champ pour la résistance à la cécidomyie de sésame, à Ngetta, Institut Zonal de Recherche Développement en Agriculture (ZARDI) au nord de l'Ouganda. La technique d'épandage en ligne a été utilisée dans le but d'accroitre la pression d'insecte sur les génotypes testés. La méthode2, modèle 1 de croisements diallèle sans réciproques a été utilisée sur $5 \times 5$ parents. Le résultat montre que l'action non additive des gènes est très importante dans l'hérédité de la cécidomyie de sésame. L'analyse des croisements a montré que l'habileté combinatoire générale (GCA) et l'habileté combinatoire spéciale (SCA) montrent varient de façon significative d'un site à un autre $(\mathrm{P}<0.05)$, ceci indique que l'effet additif et non additif des gènes contrôlent l'hérédité de la résistance à la cécidomyie de sésame de façon simultanée. L'évaluation de l'héritabilité au sens strict a montré que le caractère résistant n'est hautement héritable. L'estimation des effets de GCA et SCA suggère que le parent Local158, était le meilleur combineur pour la résistance à la cécidomyie de sésame, tandis que le parent AjimoA1-5 était le pire combineur. Les croisements 
Local158 x 7029-1-2 et Sesim1 x AjimoA1-5 étaient les meilleurs pour la résistance à la galle de sésame. Les estimations des effets génétiques pour la résistance à la cécidomyie de sésame a montré la prédominance d'épistasis de type additive et additive $\mathrm{x}$ additive dans l'hérédité de la résistance à la galle de sésame, bien que la dominance aussi joue un rôle dans le croisement Sesim1 x 7020-1-2.

Mots Clés: Asphondylia sesami, Habileté combinatoire, GCA, Sesamum indicum

\section{INTRODUCTION}

Sesame (Sesamum indicum L.) is one of the oldest oilseed crops and it is grown in tropical and subtropics in about 70 countries. The seed is rich in oil (50-60 \%) (Samara et al., 2009). In Uganda it plays a major role as a cash crop, for domestic use and export (Ssekabembe, 2007), especially in eastern and northern Uganda (Munyua and Okwadi, 2013). However, the production in Uganda is below $700 \mathrm{~kg} \mathrm{ha}^{-1}$ (FAOSTAT, 2013), which is still far below the potential yield of 2000 $\mathrm{kg} \mathrm{ha}^{-1}$ (Brigham,1985).

The low productivity in Uganda is in part caused by various constraints, including diseases and pests (Ssekabembe et al., 2006). Thirty eight insect pest species have been reported to affect sesame, of which sesame gall midge (Aphondylia sesami Felt) and webworm (Antigastra catalaunalis Dup) are the most devastating (Egonyu et al., 2005).

Midge fly lays eggs on the flower buds; the eggs develop into larvae and start feeding from inside flowers, resulting in the flower abortion or developing abnormal capsules. These manifest in three forms, namely, reinform capsules, double capsules or spherical capsules. These reduce seed yield by up to $100 \%$ in susceptible genotypes and under favourable conditions (Mehalingam, 2012). Capsule damage due to gall midge of up to 29-34.3\% has been reported in Uganda (Egonyu et al., 2005).

Chemical control has not been effective in controlling gall midge, since larvae hide inside the capsules (Egonyu et al., 2009). Breeding for host plant resistance is believed to be the most effective, efficient and most workable control measure for the resource poor farmers (Bayoumi and El-Bramawy, 2007). Some source of resistance which have been identified among the breeding lines in Uganda (Ogwal et al., 2003), could be utilised in sesame breeding against sesame gall midge, after understanding their inheritance patterns. On the other hand, the source of resistance to insect pests of sesame has been identified among breeding lines in Uganda, and very hairy genotypes have shown low damage by gall midge (Ogwal et al., 2003).

Combining ability studies provide information on additive and non-additive variances (Chandra, 2011), and also identify parents with good general and specific combining abilities. Larger genotypes $\mathrm{x}$ environment interaction effects tend to be a problem in breeding, because of lack of predictability response which hinders progress from selection (Haddadi et al., 2013). It is, therefore, necessary to identify crosses that present, not only wide adaptation, but also high stability across environments. This study aimed at investigating the nature of gene action governing the inheritance of resistance to sesame gall midge and to identify parents with good GCA and crosses with good SCA effects and help in identification of sources of resistance for breeding.

\section{MATERIALS AND METHODS}

Experimental sites. The study was conducted at two stations in Serere district in eastern Uganda, and Ngetta Zonal Agricultural Research Development Institute (ZARDI) in northern Uganda. The Serere site is located at latitudes of $1^{\circ} 30 \mathrm{~N}$ and $33^{\circ} 33 \mathrm{E}$ and altitude of $1,085 \mathrm{~m}$ above sea level, with average annual rain fall of 1,0001,200 mm per year (Wambi et al., 2014). Ngetta ZARDI is located at $2^{\circ} 17^{\prime} \mathrm{N}$ and $32^{\circ} 56^{\prime} \mathrm{E}$, at 1,180 $\mathrm{m}$ above sea level and receives mean annual rainfall of $1305.3 \mathrm{~mm}$, with a temperature range from $15-32^{\circ} \mathrm{C}$ (Otim et al., 2015).

Genetic materials and experimental design. Thirty genotypes, including local varieties, breeding lines and recent introductions at 
National Semi-Arid Resources Research Institute (NaSAARI) were used in the study (Table 1). The screening study was conducted under field conditions, in an alpha lattice design ( 5 plots x 6 blocks), with three replications. Plot size was $5 \mathrm{~m}$ x $4 \mathrm{~m}$, containing six rows per plot planted at a spacing of $30 \mathrm{~cm} \times 10 \mathrm{~cm}$. Rows of the most susceptible genotype (Sesim1) were planted between and around the test plots, two weeks earlier, in order to increase pest pressure on the evaluated genotypes.

Five genotypes were crossed in $5 \times 5$ half diallel mating design method 2, model-1 (Griffing, 1956). Ten $\mathrm{F}_{1}$ progenies, along with their parents, were evaluated in a randomised complete block design

TABLE 1. Characteristics of Sesame germplasm lines included in the study conducted at Serere and Ngetta in Uganda

\begin{tabular}{|c|c|c|}
\hline Entries & Origin & Level of resistance $^{*}$ \\
\hline Local158-1 & Egypt & Resistance \\
\hline Local158-2 & Egypt & Resistance \\
\hline Local158-3 & Egypt & Resistance \\
\hline Local158-4 & Egypt & Resistance \\
\hline Local158-5 & Egypt & Resistance \\
\hline Renner1-3-1-1 & USA & Unknown \\
\hline Renner1-3-1-16 & USA & Unknown \\
\hline $7029-1-2$ & Thailand & Susceptible \\
\hline Sesim2 & Uganda & Moderate resistance \\
\hline Sesim1 & Uganda & susceptible \\
\hline Adong4-4 & Uganda & Susceptible \\
\hline AjimoA1-5 & Uganda & Susceptible \\
\hline AjimoA1-6 & Uganda & Susceptible \\
\hline Oyamhairy & Uganda & Susceptible \\
\hline (Sesim2//5181)-2-2-1 & Uganda & Unknown \\
\hline Em15-1-5 & Uganda & Unknown \\
\hline ICEASE00020 & Uganda & Unknown \\
\hline $1438-1-10-2-1$ & Uganda & Unknown \\
\hline (Local158//7029)-7 & Uganda & Unknown \\
\hline $1438-1-6-3$ & Uganda & Unknown \\
\hline $1438-1-6-1-1$ & Uganda & Unknown \\
\hline (Local158//6022)-2-1 & Uganda & Unknown \\
\hline $49-7$ & Uganda & Unknown \\
\hline ICEASE0005 & Uganda & Unknown \\
\hline (AjimoA1-6//7029)-1-9 & Uganda & Unknown \\
\hline Em15-3-2 & Uganda & Unknown \\
\hline $1438-1-6-18-1$ & Uganda & Unknown \\
\hline (Y-1//Local158)-1-2-1 & Uganda & Unknown \\
\hline (AjimoA1-6//7029)-1-1 & Uganda & Unknown \\
\hline (A1)-1-1-1 & Uganda & Unknown \\
\hline
\end{tabular}

*Information from NaSARRI
(RCBD), with three replications in two sites. In each location, the single row plot of $2 \mathrm{~m}$ long was used. The experiment was allowed natural infestation as no protection measures were undertaken, but all the agronomic practices were applied to ensure good crop growth.

Generation mean analysis was carried out in five crosses of susceptible $\mathrm{x}$ susceptible (Sesim1 x 7029-1-2, AjimoA1-5 x 7029-1-2), resistant x susceptible (Sesim2 x AjimoA1-5, Local158 x Sesim1), and resistance $\mathrm{x}$ resistance (Sesim $2 \mathrm{x}$ Local158). The $\mathrm{F}_{1}$ of each cross was backcrossed to both parents to produce $\mathrm{BC}_{1}$ and $\mathrm{BCP}_{2}$ generations; while some of the $\mathrm{F}_{1}$ plants were selfed to produce $\mathrm{F}_{2}$ seeds. The five populations were planted in a RCBD, with three replications. The number of rows varied as follows: one row for non-segregating generations $\mathrm{P}_{1}, \mathrm{P}_{2}$ and $\mathrm{F}_{1}$; eight rows for the $\mathrm{F}_{2}$ and six rows for the $\mathrm{BCP}_{1}$ and $\mathrm{BCP}_{2}$. All recommended agronomic practices were applied, except chemical spray against pests.

\section{Data collection}

Screening. Galled capsules were recorded at 8, 10 and 12 weeks after crop emergence, by counting the number of formed and galled capsules on 10 randomly selected plants per tested genotype in each plot. The level of incidence was obtained by dividing the number of infested capsules by the total number of capsules per plant and multiply by 100 .

Genetic study. Five randomly selected plants were used for recording damaged capsules and total number of capsules per plant in the diallel. For generation mean analysis, the number of selected plants was varied as follows: 15 plants in $\mathrm{P}_{1}, \mathrm{P}_{2}$ and $\mathrm{F}_{1}, 45$ plants in $\mathrm{BCP}_{1}$ and $\mathrm{BCP}_{2}$ and 60 plants in $\mathrm{F}_{2}$ in each replication.

\section{Data analysis}

Screening. The percentage of galled capsules per cultivar was used for analysis of variance. Means were separated using Fisher's protected Least Significant Difference test, at $5 \%$ probability level. The 12 weeks score was used because it had a high $F$ value, which separated means clearly. The resistance was categorised by the scale of 
0-10 (resistance), 11-20 (moderate resistance), 21-30 (moderate susceptible), 31-50 (susceptible) and above 50 (highly susceptible) used by Solanki et al. (2006) for categorising resistance for leaf webber, and capsule borer in sesame was used.

Genetic analysis. Analysis of variance for single sites and across sites was computed using GenStat statistical (14 ${ }^{\text {th }}$ Edition) Software. The Griffing (1956) method 4, Model 1, which includes only direct $F_{1}$ crosses without parents and reciprocals, was used to estimate general and specific combining ability effects. The GCA and SCA values and the respective variance components were calculated and used to determine Baker's ratio in order to estimate the relative importance of additive and non-additive gene effects (Baker, 1978).

$\left.\mathrm{BR}=\quad \underline{(2} \underline{\sigma}^{2} \underline{\mathrm{GCA}}\right)$

$\left(2 \sigma^{2} \mathrm{GCA}+\sigma^{2} \mathrm{SCA}\right)$

Where: $\mathrm{BR}=$ Baker's ratio, $2 \sigma^{2} \mathrm{GCA}=$ variance due to GCA, and $2 \sigma^{2} \mathrm{SCA}=$ variance due to SCA. Since the parents were considered to be fixed effects factor, heritability was estimated on entry mean basis, in forms of broad-sense coefficient of genetic determination (BS.CGD), which is the total genetic variations and narrow sense coefficient of genetic determination (NS.CGD) the heritable proportion (Dabholkar, 1992).

\section{BS.CGD $=\left(\underline{2} \underline{\sigma}^{2} \underline{\mathrm{GCA}}+\underline{\sigma^{2}} \underline{\mathrm{SCA}}\right)$ $\left(2 \sigma^{2} \mathrm{GCA}+\sigma^{2} \mathrm{SCA}+\sigma^{2} \mathrm{e}\right)$}

Where: BS.CGD = Estimated broad sense heritability; $\sigma^{2} \mathrm{GCA}=$ Variance due to additive effects; $\sigma^{2}$ SCA = Variance due to dominance effects; and $\sigma^{2} \mathrm{e}=$ Environmental error variance

$$
\text { NS.CGD }=\frac{\left(\underline{2}^{2} \underline{\underline{G C A}}\right)}{\left(2 \sigma^{2} \mathrm{GCA}+\sigma^{2} \mathrm{SCA}+\sigma^{2} \mathrm{e}\right)}
$$

Where: NS.CGD= Estimated narrow sense heritability; $\sigma^{2} \mathrm{GCA}=$ Variance due to additive effects; $\sigma^{2} \mathrm{SCA}=$ Variance due to dominance effects; and $\sigma^{2} \mathrm{e}=$ Environmental error variance.
Regression analysis (generalised linear model) was used to estimate the genetic effects (additive, dominance, additive $\mathrm{x}$ additive and additive $\mathrm{x}$ dominance) from six generations using Bernardo method (2010), by fitting the model one by one until the lack of fit became non-significant.

\section{RESULTS AND DISCUSSION}

Characterisation of genotypes. None of the genotypes was free from gall midge attack (Table 2). Out of the 30 genotypes screened, 8 were moderately resistant with galled capsules ranging from 16.5 to $19.7 \%$. The introduced genotypes, Local 158-5, Local 158-4, Local 158, Local 158-1 and Local 158-2, with hairy stems, capsules and leaves showed better resistance to sesame gall midge than the non-hairy cultivars.

Similar results were reported by Ogwal et al. (2003) among breeding lines in Uganda. Singh et al. (1990) also reported that sesame genotypes with dense trichomes on the leaf surface, flowers and pods experienced less damage by web worm than the other genotypes. Genotype Sesim2, a commercial variety in Uganda, with purple colour on leaves, flowers and pods showed moderate resistance to sesame gall midge compared with other local variety with green colour on leaves, flowers and pods.

Orientation of insects towards the plant is influenced by plant architecture and colour, but the colour stimulus plays the most important role (Dent, 1993). Genotype Renner1-3-1-16, which is greenish and hairless also showed moderate resistance to gall midge, suggesting that they may possess biochemical repellants (antixenosis) or antibiotic.

Combining ability and heritability. The estimates of GCA and SCA effects from single and across two sites are presented in Table 3. Only Local158 had a significant $(\mathrm{P}<0.01)$, but negative GCA effect for percent galled capsules under Ngetta conditions, and non-significant negative GCA effects at Serere and across sites.

The parent, Sesim2, also showed a consistent non-significant negative GCA effect in single site and across sites (Table 3), which is the trend for resistance that would be passed onto crosses in 
TABLE 3. General combining ability effects (GCA) of Sesame genotypes at Serere and Ngetta in Uganda

\begin{tabular}{|c|c|c|c|c|}
\hline & Parents & Serere & Ngetta & Across locations \\
\hline \multicolumn{5}{|l|}{ GCA } \\
\hline & Sesim1 & 2.83 & 3.54 & 3.19 \\
\hline & Sesim2 & -3.2 & -3.09 & -3.14 \\
\hline & AjimoA1-5 & -0.41 & $12.01^{* * *}$ & 5.80 \\
\hline & Local 158 & -2.55 & $-9.56^{\star \star}$ & -6.05 \\
\hline & $7029-1-2$ & 3.33 & -2.89 & 0.22 \\
\hline \multicolumn{5}{|l|}{ SCA } \\
\hline & AjimoA1-5 x 7029-1-2 & -2.27 & $7.77^{\star}$ & 2.75 \\
\hline & AjimoA1-5 x Local 158 & 2.47 & $8.73^{*}$ & 5.59 \\
\hline & Local $158 \times 7029-1-2$ & -3.47 & $-22.27^{\star \star \star}$ & $-12.88^{* *}$ \\
\hline & Sesim1 x 7029-1-2 & $5.38^{*}$ & $8.23^{*}$ & 6.80 \\
\hline & Sesim1 x AjimoA1-5 & -1.89 & $-13.27^{\star \star}$ & -7.58 \\
\hline & Sesim1 x Local 158 & -0.21 & $10.80^{* *}$ & 5.30 \\
\hline & Sesim1 x Sesim2 & -3.28 & -5.77 & -4.52 \\
\hline & Sesim2 x 7029-1-2 & 0.37 & 6.27 & 3.32 \\
\hline & Sesim2 x AJimoA1-5 & 1.70 & -3.23 & -0.76 \\
\hline & Sesim2 x Local 158 & 1.21 & 2.73 & 1.97 \\
\hline & Standard error & 2.24 & 3.82 & 4.53 \\
\hline
\end{tabular}

Significance level, ${ }^{*}=\mathrm{P}<0.05,{ }^{* *}=\mathrm{P}<0.01$ and ${ }^{* * *}=\mathrm{P}<0.001$

which it would be involved. On the other hand, parent AjimoA1-5 showed a significant $(\mathrm{P}<0.001)$ positive GCA effect at Ngetta, which was an undesired direction for the trait of interest for hybridisation (Dabholkar, 1992). In the case of SCA effects, the results showed that the cross Sesim1 x 7029-1-2 had a significant $(\mathrm{P}<0.05)$ positive effect at Serere and Ngetta, and was rated a poor combiner.

Crosses, Sesim1 x AjimoA1-5 and Local158 x 7029-1-2, were the best combiners for resistance to gall midge in single and across environment (Table 3). On the other hand, the crosses AjimoA1-5 x 7029-1-2 and AjimoA1-5 x Local158, with positive significant $(\mathrm{P}<0.05) \mathrm{SCA}$ effect and Sesim $1 \times$ Local158 with significant $(\mathrm{P}<0.01)$ positive effects were recorded as the poor combiners for resistance to gall midge under Ngetta conditions. Crosses of good combiners would be desirable in hybridisation for resistance to gall midge according to Dabholkar (1992).

In this study, it was observed that combining good $x$ good parents not always results in desirable SCA effects as in cross of Sesim $2 \times$ Local 158 (moderate $\mathrm{x}$ moderate resistant parents) resulted in undesirable SCA effects and Sesim $1 \mathrm{x}$
AjimoA1-5 (poor $x$ poor parents) result in desirable SCA effects. Similar observations were reported by Nsabiyera et al. (2013) in hot pepper and Hannan et al. (2007) in tomato.

Mean squares due to GCA and SCA are presented in Table 4. The results from Serere showed no variations among the genotypes GCA and SCA for resistance to gall midge, but there were significant $(\mathrm{P}<0.001)$ variations among genotypes under Ngetta conditions. This suggests evidence of influence of environment in the expression of mode of inheritance.

The combined analysis of variance across the two locations showed differences, again suggesting that multi-locations may be necessary for resistance selection. This was further confirmed by $\sigma^{2}$ GCA $x$ location and $\sigma^{2}$ SCA $x$ location, indicating that the crosses had dissimilar performance for resistance to sesame gall midge for the two sites. This clearly shows that when developing a breeding programme for resistance to gall midge, environmental factors ought be considered. This was also proposed by Nzuve et al. (2013) while working on grey leaf spot and yield traits in maize inbred lines. The variance due to SCA $x$ location was greater than 
that due GCA x location, suggesting that nonadditive gene action was more important than additive. The important role of non-additive gene action was further demonstrated by low Baker's ratio (0.31), thus suggesting that best progeny cannot be obtained by crossing two parents with low capsules infestation (Baker, 1978). The imprortant role of non-additive gene action was earlier reported in sesame, for resistance to leaf webber and capsule borer, by Gnanasekaran et al. (2010). Similar results were reported earlier by Solanki et al. (2006).

Broad sense heritability was medium (0.43) (Table 4), indicating the significant role of environmental effects in the variations observed for resistance to gall midge (Akinwale et al., 2011).

TABLE 4. Variance component for resistance to gall midge

\begin{tabular}{lccc}
\hline Source of variation & Serere & Ngetta & Across sites \\
\hline$\sigma^{2}$ GCA & 5.7 & 56.8 & 7.4 \\
$\sigma^{2}$ SCA & 4.2 & 187.5 & 33.5 \\
$\sigma^{2}$ GCA x site & - & - & 23.8 \\
$\sigma^{2}$ SCA x site & - & - & 62.3 \\
BS.CGD & 0.61 & 0.91 & 0.43 \\
NS.CGD & 0.44 & 0.34 & 0.13 \\
Baker's ratio & 0.73 & 0.38 & 0.31 \\
\hline
\end{tabular}

${ }^{*}=\mathrm{P}<0.05,{ }^{*}=\mathrm{P}<0.01$ and ${ }^{* * *}=\mathrm{P}<0.001=$ significance levels.,$\sigma^{2} \mathrm{GCA}=$ variance due to $\mathrm{GCA}, \sigma^{2} \mathrm{SCA}=$ variance due to SCA, $\sigma^{2} \mathrm{GCA} \times$ sit $e=$ variance due to interaction between genotype by site and $\sigma^{2} S C A x$ site $=$ variance due to interaction between crosses by site, BS.CGD and NS.CGD = broad sense and narrow sense coefficients of genetic determination respectively
The narrow sense heritability was very low (0.13), indicating that resistance to sesame gall midge had a high environmental effect and non-additive gene effects, making the value of NS.CGD to be low. During improvement of resistance through selection, early selection would not be effective due to the masking effects of the environment.

The estimates of genetic effects for resistance to sesame gall midge are presented in Table 5 . Gene effects varied among crosses; thus, simple additive/dominance model was adequate to explain the inheritance of resistance in crosses Local $x$ Sesim 1 and Sesim 2 x AjimoA1. This suggests that improvement can be achieved through pedigree breeding procedure. The inheritance was more complex in the crosses, Sesim 1 x 7029-1-2, AjimoA1-5 x 7029-1-2 and Sesim $2 \times$ Local 158 as shown by the significant lack of fit.

In general the inheritance of resistance in these crosses was controlled by additive $\mathrm{x}$ additive epistasis, though dominance and additive were also having effect in crosses Sesim1 x 7029-1-2 and AjimoA1-5 x 7029-1-2, respectively, for the improvement selfing within those crosses would be the best approach to capture the epistasis and dominance effects.

\section{CONCLUSION}

Genotypes used in this study possess reaction to sesame gall midge, indicating that materials are diverse. Genotypes, Local158, Sesim2 and Renner1-3-1-1 with moderate resistance can be

TABLE 5. Estimates of genetic effects of five crosses of Sesame in a study conducted in Serere in Uganda

\begin{tabular}{llllll}
\hline Source of variation & $\begin{array}{l}\text { Sesim1 } x \\
7029-1-2\end{array}$ & $\begin{array}{c}\text { ajimoA1-5 } x \\
7029-1-2\end{array}$ & $\begin{array}{c}\text { Local158 } x \\
\text { Sesim1 }\end{array}$ & $\begin{array}{l}\text { Sesim2 } x \\
\text { AjimoA1-5 }\end{array}$ & $\begin{array}{c}\text { Sesim2 } x \\
\text { Local158 }\end{array}$ \\
\hline a & 2.8 & $12.3^{*}$ & $91.7^{* * *}$ & $64.0^{*}$ & 0.3 \\
$\mathrm{~d}$ & $33.0^{* * *}$ & 6.0 & 0.7 & 15.5 & 1.8 \\
aa & $15.6^{* *}$ & $16.4^{*}$ & - & - & $20.5^{*}$ \\
ad & 4.0 & 3.6 & - & - & 1.6 \\
Lack of fit & $2.0^{*}$ & $1.8^{*}$ & - & - & $11.7^{*}$ \\
Total & 11.5 & 7.6 & - & - & 7.2 \\
Residual & 1.3 & 2.2 & & & 2.8 \\
\hline
\end{tabular}

Significant differences at ${ }^{*}=P<0.05,{ }^{* *}=P<0.01$ and ${ }^{* *}=P<0.001 . a=$ additive, $d=$ dominance, aa $=$ additive $x$ additive and ad $=$ additive $x$ dominance 
good sources for future breeding. The estimated low (0.31) Baker's ratio indicated that nonadditive gene effect is more important than additive gene effects in determining sesame gall midge resistance in sesame genotypes evaluated in this study. The results from generation mean analysis show predominance of additive and additive $\mathrm{x}$ additive type of epistasis in the inheritance of resistance to sesame gall midge, though dominance also has a role in the cross Sesim1 x 7020-1-2. With respect to GCA effects, parents Local158 and sesim 2 are the best combiners for resistance to gall midge. On the other hand, for SCA effect, the cross Local $158 \mathrm{x}$ 7029-1-2 would be the best choice. The low narrow sense heritability $(0.13)$ obtained in this study implies that improvement through selection at early generation may not be effective. Moderate (0.43) broad sense heritability obtained in this study indicates the role of environmental effects on the expression of the resistance.

\section{ACKNOWLEDGEMENT}

This work was funded by the Alliance for Green Revolution in Africa (AGRA), and supported by Makerere University, College of Agricultural and Environmental Sciences (CAES), the National Semi-Arid Resources Research Institute (NaSARRI), of National Agricultural Research Organisation (NARO), Uganda.

\section{REFERENCES}

Abebe, H., Setegn, G. and Habtamu, Z. 2013. Generation mean analysis and heritability of drought resistance in common bean (Phaseolus vulgaris L.). African Journal of Agricultural Research 8 (15):1319-1329.

Akinwale, M., Gregorio, G., Nwilene, F., Kinyele, B., Ogunbayo, S. and Odiyi, A. 2011. Heritability and correlation coefficient analysis for yield and its components in rice (Oryza sativa L.). African Journal of Plant Science 5 (3):207-212.

Baker, R. 1978. Isssues in diallel analysis. Crop Science 18 (4):533-536.

Bayoumi, T. and El-Bramawy, M. A. 2007. Genetic analyses of some quantitative characters and fusarium wilt disease resistance in sesame.
In: African Crop Science Conference Proceedings 8:2198-2204.

Bernardo, R. 2010. Generations mean analysis. In: Breeding for quantitative traits in plants. Twin Cities: University of Minnesota, USA. pp.173-174.

Brigham, R. D. 1985. Status of sesame research and production in Taxs and USA. Sesame and safflower status and potentials. FAO, Rome, Italy. pp. 73-74.

Chandra, B.S. 2011. Combining ability studies for development of new hybrids over environments in sun flower (Helianthus annus L.). Journal of Agricultural Science 3 (2):230-237.

Dabholkar, A. 1992. Elements of biometrical genetics. Concept Publishing Company, New Delhi, India.

Egonyu, J., Kyamanywa, S., Anyanga, W. and Ssekabembe, C. 2005. Review of pests and diseases of sesame in Uganda. Africa Crop Science Conference Proceedings 7:1411-1416.

Egonyu, J.P., Kyamanywa, S. and Ssekabembe, C. K. 2009. Integration of time of planting and insecticide application schedule to control sesame webworm and gall midge in Uganda. Journal of Applied Biosciences 18:967-975.

FAOSTAT. 2013. FAO database. Food and Agricultural Organization of the United Nation, Rome, Italy.

Gnanasekaran, M., Jebaraj, S. and Muthuramu, S. 2010. Breeding for seed yield and shoot webber (Antigastra catalaunalis D.) resistance in sesame (Sesamum indicum L.). Electronic Journal of Plant Breeding 1 (4):1270-1275.

Griffing, B. 1956. Concept of general and specific combining baility in relation to diallel crossing systems. Australian Journal of biological Science 9:463-493.

Haddadi, M. H., Maqsadollah, E. and Rajab, C. 2013. Determination of genetic heritability for some agronomic traits in corn by diallel analysis. International Journal of Agriculture and Crop Sciences 5 (15):16871693.

Hannan, M. M., Ahmed, M. B., Roy, U. K., Razvy, M. A., Haydar, A., Rahman, M. A., Islam, M. A. and Islam, R. 2007. Heterosis, combining ability and genetics for brix \%, days to first 
fruit ripening and yield in tomato (Lycopersicon esculentum Mill.). MiddleEast Journal of Scientific Research 2 (34):128-131.

Mehalingam, P. 2012. Morphological and anatomical studies of the ovary galls of Sesamum indicum L. Induced by the gall midge, (Asphondylia sesami Felt.). Journal of Ornamental and Horticulural Plants 2 (3):191-200.

Munyua, B. and Okwadi, A. 2013. Open Sesame: A value chain analysis of sesame marketing in northern Uganda. International Crops Research Institute for the Semi-Arid Tropics (ICRISAT), Nairobi, Kenya.

Nsabiyera, V., Ochwo-ssemakula, M., Sseruwagi, P., Ojewo, C. and Gibson, P. 2013. Combining ability for field resistance to disease, fruit yield and yield factors among hot pepper (Capsicum annuum L.) genotypes in Uganda. International Journal of Plant Breeding 7 (1):12-21.

Nzuve, F., Githiri, S., Mukunya, D. and Gethi, J. 2013. Combining abilities of maize inbred lines for grey leaf spot ( GLS ), grain yield and selected agronomic traits in Kenya. Journal of Plant Breeding and Crop Science 5 (3):4147.

Ogwal, S., Anyanga, W., Odul, C. and Oumo, J. 2003. Screening of sesame breeder's lines for resistance/ tolerance to gall midge and sesame webworb insect pests of sesame. NAROARTP2 Annual Report 2002-2003. National Agricultural Research Organisation, Ministry of Agriculture Animal Industry and Fisheries, Kampala, Uganda.
Otim, G.A., Mubiru, D.N., Lwasa, J., Namakula, J., Nanyeenya, W., Okello, R. and Elem, J. 2015. Evaluating permanent planting basin for optimum plant populations of maize and beans. Journal of Environmental and Agricultural Sciences 2:2.

Samara, M.E., Sedeek, F.S. and El-Shimy, A. 2009. Genetic analysis of sesame yield via quadrallel mating system. Egyptian Journal of Genetic Cytology 38:55-71.

Singh, H., Jaglan, R. and Khrub, S. 1990. Antibiosis in some sesame genotypes against shoot webber and pod borer, Antigastra catalaunalis (Duponchel). Journal of Insect Sciences 3:174-176.

Solanki, Z. S., Singh, I., Rajpurohit, T. S. and Ahuja, D. B. 2006. Combining ability and heterosis for stem and root rot and leaf webber/ capsule borer in sesame. Indian Journal of Crop Science 1 (1-2):171-174.

Ssekabembe, C., Okidi, J., Latigo-Ogenga, M. and Nabasirye, M. 2006. Occurrence and species range of insect pests of simsim in northern and eastern Uganda. Makerere University Research Journal (MURJ), 6:25-35.

Ssekabembe, C.K. 2007. Comparison of research on sesame (Sesamum indicum) and nakati (Solanum aethiopicum) at Makerere University. In: African Crop Science Conference Proceedings 8:2063-2069.

Wambi, W., Tukamuhabwa, P., Puppala, N., Okello, D. K. and Nalugo, R. G. 2014. Narrow sense heritability and gene effects for late leaf spot resistance in Valencia groundnuts. African Crop Science Journal 22 (4):327-336. 